\title{
Agenda Control, the Median Justice, and the Majority Opinion on the U.S. Supreme Court
}

\author{
Chris W. Bonneau University of Pittsburgh \\ Thomas H. Hammond Michigan State University \\ Forrest Maltzman George Washington University \\ Paul J. Wahlbeck George Washington University
}

\begin{abstract}
Some scholars argue that the author of the majority opinion exercises the most influence over the Court's opinion-writing process and so can determine what becomes Court policy, at least within the limits of what some Court majority finds acceptable. Other students of the Court have suggested that the Court's median justice effectively dictates the content of the majority opinion: whatever policy the median justice most wants, she can get. We test these competing models with data on Supreme Court decision making during the Burger Court (1969-86). While we find substantial evidence for both models, the agenda control model gains greater support. This suggests that opinions on the Court on each case are driven, in general, by the interaction of three key variables: the policy preferences of the majority opinion author, the policy preferences of the median justice, and the location of the legal status quo.
\end{abstract}

1 fter a half century of research on decision making by the Supreme Court, a key question remains unanswered: what policy will be prescribed by the Court's majority opinion in each case? To understand the development of the majority opinion, and thus of the resulting law, we need to know which justice or justices most influence the Court's opinions. Answering this question depends upon knowing the relative power of each justice to shape the opinion.

The failure by empirically oriented legal scholars to address this question stems from a widespread belief that the justices' policy preferences alone determine the decisions they make and that a majority of the Court must join an opinion before it has the force of law. As a result, it is argued that decision making is driven simply by the median justice's policy preferences. This view is reflected in Spiller's assertion about the development of the law on the Court: "Once the median is proposed, no other proposal will beat it, and it becomes the outcome" (2000, 943). ${ }^{1}$

In contrast to this view that the median can dictate outcomes, other scholars assert that the majority opinion author has the most impact on the opinion (see, e.g., Epstein and Knight 1998, 95-107; Murphy 1964, Chap. 3). Justices themselves appear to view opinion assignment as critically important; as Justice Fortas once noted, "If the Chief Justice assigns the writing of the Court to Mr. Justice $\mathrm{A}$, a statement of profound consequence may emerge. If he assigns it to Mr. Justice B, the opinion of the Court may be of limited consequence" $(1975,405)$. Of course, those who believe that the median justice dictates outcomes believe the importance of the opinion assignment process has

Chris W. Bonneau is assistant professor of political science, University of Pittsburgh, Pittsburgh, PA 15260 (cwb7@pitt.edu). Thomas H. Hammond is professor of political science, Michigan State University, East Lansing, MI 48824-1032 (thammond@msu.edu). Forrest Maltzman is professor of political science, George Washington University, Washington, DC 20052 (forrest@gwu.edu). Paul J. Wahlbeck is professor of political science, George Washington University, Washington, DC 20052 (wahlbeck@gwu.edu).

An earlier version of this manuscript was presented at the 2004 meeting of the Midwest Political Science Association. The authors gratefully acknowledge the advice of Sarah Binder, Eric Lawrence, Reggie Sheehan, Don Songer, and Jim Spriggs. We are particularly grateful for the advice, contributions, and friendship of Saul Brenner.

${ }^{1}$ Arguments about the power of the median justice have stimulated additional hypotheses. One is that the opinion assigner will assign opinions to the median justice to attract her critical fifth vote (Maltzman, Spriggs, and Wahlbeck 2000; Rohde and Spaeth 1976; though see Brenner and Spaeth 1988). This emphasis on the median is also consistent with models of the appointment process that focus on the location of the Court median relative to the president and Senate median (Bailey and Chang 2001; Moraski and Shipan 1999; Shipan and Shannon 2003).

American Journal of Political Science, Vol. 51, No. 4, October 2007, Pp. 890-905 
been overstated. For example, Lax and Cameron note: "It is not obvious that assignments should matter ... if bargaining inevitably drives the position of cases to the ideal point of the median voter, it does not matter who writes the initial opinion and thus it does not matter who makes the assignment" $(2001,2)$. These two lines of argumentthat majority opinion writing is most influenced by the median justice, and that opinion writing is most influenced by the opinion author-have coexisted for some time without resolution. This led Segal and Spaeth to ask, "Are majority opinions written at the median of the Court... or does the opinion writer have special influence?" $(2002,434)$. We take this question as our point of departure.

We begin by characterizing two competing models (see Hammond, Bonneau, and Sheehan 2005) regarding which justice controls the content of the final opinion. In the "agenda control" model, the justice writing the majority opinion has substantial, albeit constrained, decision-making authority to craft the majority opinion and thus the law. The opinion author is constrained because other justices-and most critically, the median justice-can choose not to join a draft majority opinion, thereby denying it majority support. The "bench median" model is a median-voter model that predicts that since final outcomes will reflect the preferences of the median justice, the Court's choice will be whatever policy the median justice most prefers.

Because these two models make divergent predictions about which justices will join the majority opinion, we compare justices' voting records to determine which model has greater empirical support. In an examination of the voting records of 11 justices during the Burger Court, we conclude by challenging the claim that the median justice alone dictates the content of opinions. Instead, we demonstrate that a sophisticated majority opinion author can take advantage of the fact that justices are likely to have some tolerance for opinions that, while preferable to the legal status quo, diverge from their most preferred policies. Although we find some support for the claim that the median can dictate outcomes, the support for such a model is weaker than the support for a model that highlights the importance of being the opinion writer. ${ }^{2}$

\footnotetext{
${ }^{2}$ Westerland (2003) has articulated a model that predicts that outcomes will be located at the most preferred policy of the median member of the majority decision coalition, rather than the median member of the entire Court. We do not test this for several reasons. First, theoretically it is the bench median who is empowered because plurality opinions do not necessarily have precedential value (see fn. 3). Second, we view coalition formation and opinion writing to be interdependent activities. A theory that attributes a pivotal role to the majority coalition median rests on the assumption
}

\section{Two Models of Majority Opinion Writing and Coalition Building}

The two models of majority opinion formation examined here share six key assumptions. Consistent with Grofman and Brazill (2002), we assume that Supreme Court decision making for each case takes place on a single dimension. This dimension is normally interpreted as involving the justices' liberal/conservative policy preferences, though alternative interpretations, such as the justices' differing views on what constitutes "good jurisprudence," may also be plausible.

Second, for each case we assume that each justice has single-peaked preferences on this single dimension; that is, each justice has an "ideal point." The desirability of other policies for a justice drops the farther the policies diverge in either direction from the justice's ideal point. Third, we assume that justices have complete information about the location of each justice's ideal point. Fourth, we assume that justices are rational: each justice makes choices intended to produce a majority opinion that is as close as possible to his or her ideal point.

Fifth, we assume that the decision making by rational justices involves reference to the status quo policy. This status quo is the state of legal affairs that will continue if the Court either does not hear the case or fails to produce a majority opinion that does more than reiterate the current state of the law. Sixth, a justice will be expected to support the draft majority opinion only when she considers this opinion to be at least as good as the status quo policy.

The Agenda Control Model. In this model, the majority opinion author is assumed to have sole power to propose a majority opinion, and each other justice is assumed to respond either by (1) supporting the author's proposal (i.e., by joining the draft majority opinion) if that proposal is at least as close to his or her own ideal point as the status quo, or else by (2) rejecting the author's proposal (i.e., by writing or joining a dissenting opinion or special concurrence) if that proposal is farther from the justice's ideal point than the status quo; in no case does any other justice respond to the draft proposal by writing an alternative opinion to attract majority support. It thus

that this coalition is constructed prior to the opinion-writing process. Although movement between the initial coalition and the final coalition only occurs about $7.5 \%$ of the time (Maltzman and Wahlbeck 1996, 587), there is no prohibition against such movement. Third, if one assumes that each justice's vote reflects in part his or her view of the legal status quo, there are easily identifiable conditions under which an opinion at the majority coalitional median could not possibly gain majority support. Fourth, empirically it is often observationally equivalent to the models we test (see fn. 7). 
follows that rational opinion authors craft opinions that are as close as possible to their own ideal points, but that are also at least as good as the status quo policy for the median justice.

A key aspect of the agenda control model is that the opinion author will write an opinion that attracts the support of at least four other justices (always including the bench median), even though this opinion is unlikely to be at their respective ideal points. There are several reasons why a justice might support an opinion that she views as less than ideal. Perhaps most importantly, justices understand that opinions not backed by a majority are not necessarily treated as precedents (Epstein and Knight 1998; Maltzman, Spriggs, and Wahlbeck 2000; Murphy 1964). ${ }^{3}$ If all the justices insisted on their own ideal points, there would be only a plurality opinion on many cases. If the justices routinely failed to produce majority opinions, the influence of the Court in the judicial system and the larger political system might be diminished. In addition to this institutional constraint on the Court, and thus on each justice's behavior, limits on each justice's time and resources (variables not explicitly incorporated in either model) might preclude her from crafting an alternative to the majority opinion (Lax and Cameron 2001, 2005).

We should emphasize that we are not attempting to model the process by which the justices might decide to let the majority opinion author control the decision-making agenda when the opinion is being written. Our purpose here is more limited: to determine whether the majority opinion author actually appears to have some kind of agenda-control power.

The Bench Median Model. The bench median model assumes that other justices will challenge the majority opinion author by drafting alternative majority opinions. But what happens if some other justice attempts to attract a Court majority by challenging the majority opinion author? To answer this question, consider what might happen if the majority opinion author drafts an opinion that is not at the median's ideal point. In this case, there will always be other justices, including the median justice, who would benefit from another opinion that is closer to the median's ideal point. Indeed, there will always be enough justices who would also support this alternative that it would become the de facto majority opinion. The

${ }^{3}$ Before 1977 , a plurality opinion never established a precedent, but Marks v. United States (1977) declared that "the holding of the Court may be viewed as the position taken by those members who concurred on the narrowest grounds." However, since it is not always clear to the opinion author what the narrowest-grounds doctrine might turn out to be, we expect that opinion authors will still strive for a majority coalition (Maltzman, Spriggs, and Wahlbeck 2000, 16). only opinion not subject to this kind of upset is an opinion at the median's ideal point.

While the agenda control and bench median models make different predictions about the outcome of the opinion-writing process, it is important to note that the logic of both models depends on the justices' responses to the "status quo policy" on the case at hand. While the status quo has been a relatively explicit component of studies of the Court's certiorari decisions, it has less often been a component of analyses of decision making and coalition formation regarding the final opinion. Hence, it is useful to consider this key concept somewhat further.

\section{On the Concept of the "Status Quo" in Supreme Court Decision Making}

Almost every form of purposive human reasoning seeks to create a future state of affairs that the individual expects to be better than, or at least as good as, the current state of affairs. Accordingly, the status quo is an element of many decision-making theories. ${ }^{4}$ The importance of the status quo in the calculus of justices was made clear in a written exchange between Justices Brennan and Marshall during the crafting of the Pennsylvania v. Muniz (1990) opinions. Brennan justified his majority opinion by asserting:

As you will recall, Sandra forced my hand by threatening to lead the revolution.... the opinion still describes the "routine booking question" exception in narrow terms, and in my view it leaves the law no worse off than it already was before, since every circuit has already found such an exception to exist. (1990, emphasis added)

In other words, Justice Brennan was willing to draft an opinion that was acceptable to the Court median, Justice O'Connor, as long as it did not move the law in what he considered an undesirable direction from the legal status quo. Moreover, those who practice before the Court realize that justices use the status quo when evaluating potential changes in the law. For example, in accounting for his success in arguing before the Supreme Court,

\footnotetext{
${ }^{4}$ Behavioral economists see the status quo as a benchmark against which real-world actors evaluate possible changes in policy (Samuelson and Zeckhauser 1988). Some psychologists also view choices as based on a reference to the status quo (Quattrone and Tversky 1988); for instance, the notion of loss aversion appears to influence how individuals make decisions (Kahneman and Tversky 1984; Tversky and Kahneman 1991). In political science, the concept of the status quo is often an element of rational-choice theories of legislative politics, bureaucratic politics, and comparative politics (Shipan 2004; Tsebelis 2002; Volden 2002).
} 
Lawrence Wallace explained, "You have to show them why your answer to the case is not something that will do damage to the law" (Mauro 2003, 57). He understood that Brennan was not the only justice who would tolerate an outcome if it left the law "no worse off than it already was before."

Nevertheless, the status quo has rarely been incorporated in models of the Court's internal decision-making process. Instead, judicial opinions are often attributed to the justices' preferences over the two alternatives formally presented by the opposing sides (e.g., McGuire, Smith, and Caldeira 2004). Given the Court's adversarial forum, the focus on two competing alternatives may seem reasonable. However, the Court is not restricted to just these two options since majority opinions may include policies that are not advocated by either the plaintiff or the defendant (see McGuire and Palmer 1995). Moreover, there is always another option, which is simply to reaffirm the status quo by upholding the current policy. ${ }^{5}$

When a justice votes to accept a case for the Court's consideration, it is usually an indication that this justice wants to change the current legal status quo. This is true even when the justice wants to affirm a lower court decision; that is, he thinks there is some way in which the legal state of affairs can be further improved. For example, a circuit court's decision usually applies only to its own circuit, but the justice may want to extend the ruling to the nation. At the Supreme Court, the cert decision usually hinges on an evaluation of the current state of the law, rather than a desire to correct a legal mistake in a single case (Perry 1991).

Once the Court accepts a case, this might be taken to mean that the justices have thereby decided to upset the status quo, and thus that the status quo has no further relevance to their decision making. But this would be an erroneous inference. For example, due to the Court's "rule of four," as few as four justices can force the Court to hear a case, but the remaining five justices might want to maintain the status quo and so would support an opinion reaffirming the prior state of the law. The Court might even decide to protect the status quo simply by dismissing as improvidently granted ("D.I.G.") a case that it had already accepted for review. In other words, just because the Court accepts a case does not mean that the Court will necessarily change the status quo or that the status quo is irrelevant for the rest of the Court's decision-making process.

For our purposes, the nature and origins of the status quo are less important than the fact that each justice uses

\footnotetext{
${ }^{5}$ There is an appendix that further discusses this matter; it is avail-
} able at home.gwu.edu/ forrest/famresearch.html. the status quo as a benchmark for determining how she wants to change judicial policy, assuming the justice wants to change it at all. In effect, then, when writing an opinion or deciding whether to support someone else's opinion, each justice asks, "Does this majority opinion leave me at least as well off as the status quo?" If the answer is "yes," then the justice will join the opinion. If the answer is "no," the justice will not join the opinion.

\section{Illustrating the Models}

Figure 1, which shows the ideal points of nine justices on an issue dimension, provides a graphical illustration of how the agenda control and bench median models work. Seven justices, $J_{1}$ through $J_{7}$, have ideal points to the left of the status quo policy, denoted SQ, and two justices, $\mathrm{J}_{8}$ and $J_{9}$, have ideal points to the right of SQ. If the majority opinion author controls the Court's opinion-writing agenda on the case, what outcome should we expect? If a justice were unconstrained, he would presumably always write the opinion at his ideal point. However, the opinion writer must attract four other votes so as to form a majority on the Court. So if Justice $J_{1}$ is the majority opinion writer, where should she write the majority opinion?

For the agenda control model, note that all majority coalitions must include the median justice: in a unidimensional setting, it is the median justice who can supply the fifth vote for an opinion, and if she refuses to support the opinion, there will always be at least four other justices who would likewise refuse to support the opinion. But if the median justice does supply the fifth vote, the support of these other four justices will not be needed. Hence, for majority support to be gained, the opinion must be written at or inside the border of the median justice's "preferred-to set" of SQ, which is the set of policies that the median justice, denoted $\mathrm{J}_{\mathrm{med}}$, prefers to $\mathrm{SQ}$; in our notation, the opinion must always lie inside or on the boundary of $\mathrm{W}_{\text {Jmed }}(\mathrm{SQ})$.

In Figure 1, each justice's preferred-to set of SQ is depicted by a horizontal, downward-facing bracket. Thus, if Justice $J_{1}, J_{2}$, or $J_{3}$ is the majority opinion writer and Justice $\mathrm{J}_{5}$ is the median, the opinion writer will write the opinion at the location of ${ }^{*}$, which lies just inside the outside (away from $\mathrm{SQ}$ ) boundary of $\mathrm{W}_{\mathrm{J}}(\mathrm{SQ})$, which is Justice $\mathrm{J}_{5}$ 's preferred-to set. Since this policy at * also lies inside the preferred-to sets of Justices $\mathrm{J}_{1}$ through $\mathrm{J}_{4}$, these five justices-a majority of the Court-will support the policy. The policy at ${ }^{*}$ is better for these justices than $\mathrm{SQ}$, even though it is more liberal (too far to the left) than Justices $\mathrm{J}_{4}$ and $\mathrm{J}_{5}$ would have most preferred, and more conservative (too far to the right) than Justices $J_{1}$, 


\section{FIgURE 1 A Portrait of the Opinion Formation Process in a Unidimensional Issue Space}

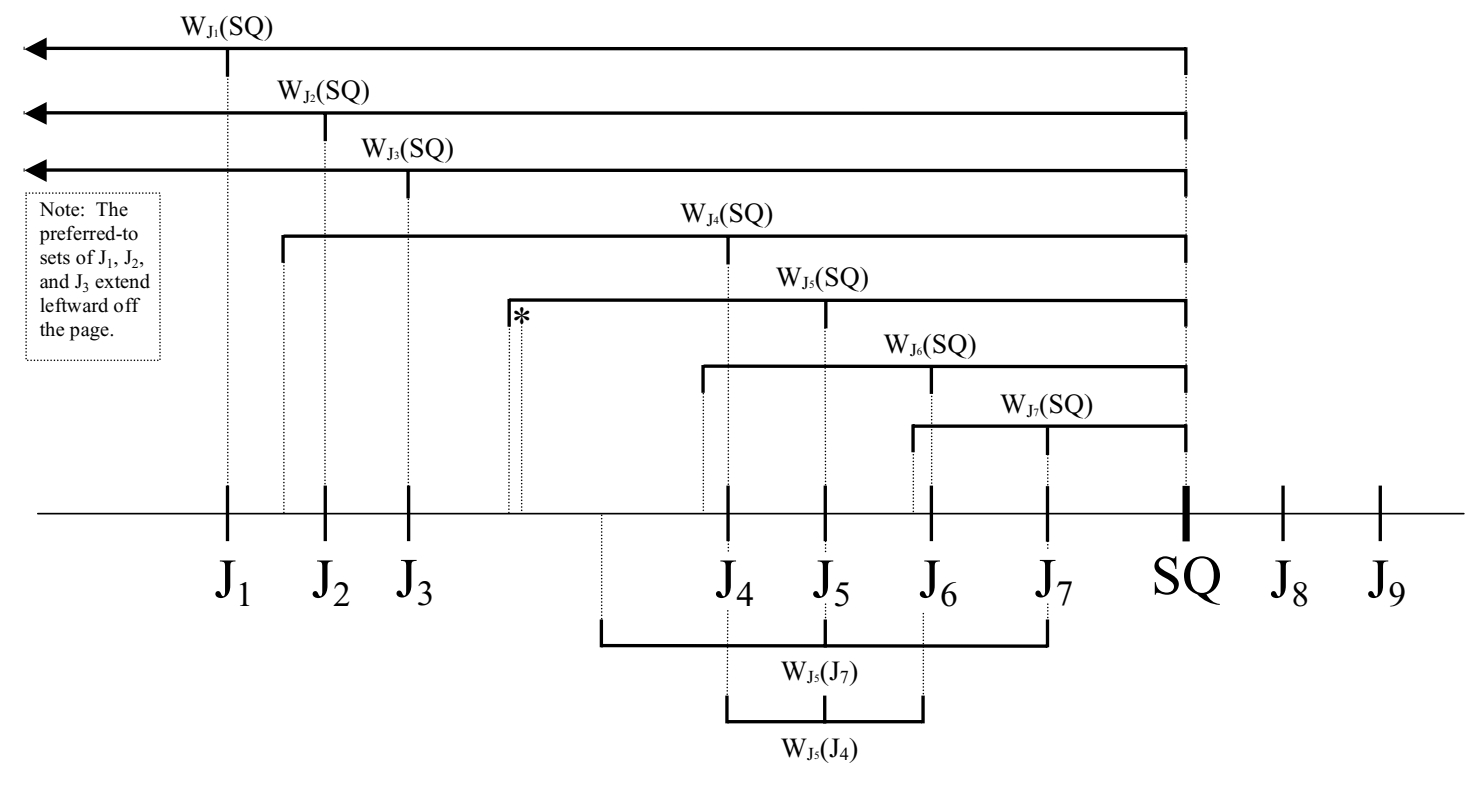

$\mathrm{J}_{2}$, and $\mathrm{J}_{3}$ would have most preferred. In contrast, note that Justices $\mathrm{J}_{6}$ through $\mathrm{J}_{9}$ would all refrain from joining the majority here because the opinion at ${ }^{*}$ is worse for them than SQ. Justices $\mathrm{J}_{6}$ and $\mathrm{J}_{7}$ would both prefer a more liberal (leftward) outcome than SQ, but the opinion at * is too liberal (too far to the left) for their tastes (i.e., ${ }^{*}$ lies to the left of their respective preferred-to sets; hence, they both prefer $\mathrm{SQ}$ to ${ }^{*}$ ). And Justices $\mathrm{J}_{8}$ and $\mathrm{J}_{9}$ would prefer a more conservative outcome (farther rightward) than SQ: they also prefer SQ to *. Hence, the draft opinion at * in Figure 1 would be supported by five justices $\left(J_{1}\right.$ through $\mathrm{J}_{5}$ ) and opposed by four justices $\left(\mathrm{J}_{6}\right.$ through $\left.\mathrm{J}_{9}\right){ }^{6}$

What happens if the opinion author is Justice $\mathrm{J}_{4}, \mathrm{~J}_{5}$, $\mathrm{J}_{6}$, or $\mathrm{J}_{7}$ ? It turns out that each is unconstrained: they can write their opinions at their own ideal points because their points all lie inside $\mathrm{W}_{\mathrm{J}}(\mathrm{SQ})$, which means that opinions

${ }^{6}$ Because our empirical analysis depends only on who supports the majority opinion, we are being deliberately vague here when indicating simply that Justices $\mathrm{J}_{6}$ through $\mathrm{J}_{9}$ "oppose" or "do not support" the majority opinion. But to flesh out an intuitive interpretation of the model, it is reasonable to think that Justices $\mathrm{J}_{8}$ and $\mathrm{J}_{9}$ will write or join a dissent from a majority opinion at * : this opinion moves policy leftward whereas Justices $\mathrm{J}_{8}$ and $\mathrm{J}_{9}$ want policy to move rightward. Justices $\mathrm{J}_{6}$ and $\mathrm{J}_{7}$ might also write or join a dissent: the opinion at* is also worse for them than SQ. But if anyone were to write a special concurrence, it might be Justices $\mathrm{J}_{6}$ and $\mathrm{J}_{7}$ : they approve of the leftward movement in policy but believe that the new policy at * has moved leftward too far. Unfortunately, our model cannot further clarify how these two justices will behave: all the model can do is make clear that they will not join the majority opinion. at $\mathrm{J}_{4}, \mathrm{~J}_{5}, \mathrm{~J}_{6}$, and $\mathrm{J}_{7}$ are all better for Justice $\mathrm{J}_{5}$ than SQ. Because opinions at $\mathrm{J}_{4}, \mathrm{~J}_{5}, \mathrm{~J}_{6}$, or $\mathrm{J}_{7}$ would all lie inside $\mathrm{W}_{\mathrm{J} 6}(\mathrm{SQ})$, Justice $\mathrm{J}_{6}$ would join these opinions as well. Justice $\mathrm{J}_{7}$ would support an opinion at $\mathrm{J}_{6}$ but prefers SQ to opinions at ${ }^{*}, \mathrm{~J}_{4}$, or $\mathrm{J}_{5}$ and so would not join those opinions. Thus, an opinion at * would generate a 5-4 vote, an opinion at $\mathrm{J}_{4}$ or $\mathrm{J}_{5}$ would generate a $6-3$ vote, and an opinion at $\mathrm{J}_{6}$ or $\mathrm{J}_{7}$ would generate a 7-2 vote.

In sum, for the Figure 1 example the agenda control model predicts that if Justice $\mathrm{J}_{1}, \mathrm{~J}_{2}$, or $\mathrm{J}_{3}$ is the majority opinion writer, each would write the opinion at *, whereas if Justice $\mathrm{J}_{4}, \mathrm{~J}_{5}, \mathrm{~J}_{6}$, or $\mathrm{J}_{7}$ is the majority opinion writer, each would write the opinion at his or her own ideal point. And the remaining justices would support the opinion if it is at least as close to his or her ideal point as SQ and would not join the opinion if it is farther from his or her ideal point than SQ.

In the bench median model, the median justice does not accept any proposal that does not produce the outcome she most prefers. If the author proposes an outcome that is not at her ideal point, the median justice is assumed to respond by writing or supporting an alternative designed to attract a Court majority. The resulting dynamic, as already described, involves a back-and-forth process that converges on a policy at $\mathrm{J}_{\mathrm{med}}$, which is the only equilibrium policy.

To illustrate this dynamic in Figure 1, suppose Justice $\mathrm{J}_{1}$ is the majority opinion writer and drafts an opinion at *. This opinion is better than SQ for Justices $\mathrm{J}_{1}$ through 


\section{TABLE 1 Summary of Outcomes for Figure 1}

\begin{tabular}{lccccccc}
\hline & \multicolumn{3}{c}{ Bench Median Model } & & \multicolumn{3}{c}{ Agenda Control Model } \\
\cline { 2 - 3 } Author & $\begin{array}{c}\text { Outcome } \\
\text { Location }\end{array}$ & $\begin{array}{c}\text { Joining } \\
\text { Justices }\end{array}$ & $\begin{array}{c}\text { Dissenting } \\
\text { Justices }^{2}\end{array}$ & & $\begin{array}{c}\text { Outcome } \\
\text { Location }\end{array}$ & $\begin{array}{c}\text { Joining } \\
\text { Justices }\end{array}$ & $\begin{array}{c}\text { Dissenting } \\
\text { Justices }^{2}\end{array}$ \\
\hline $\mathrm{J}_{1}, \mathrm{~J}_{2}$, or $\mathrm{J}_{3}$ & $\mathrm{~J}_{5}$ & $\mathrm{~J}_{1}$ to $\mathrm{J}_{6}$ & $\mathrm{~J}_{7}, \mathrm{~J}_{8}, \mathrm{~J}_{9}$ & & $*$ & $\mathrm{~J}_{1}$ to $\mathrm{J}_{5}$ & $\mathrm{~J}_{6}, \mathrm{~J}_{7}, \mathrm{~J}_{8}, \mathrm{~J}_{9}$ \\
$\mathrm{~J}_{4}$ & $\mathrm{~J}_{5}$ & $\mathrm{~J}_{1}$ to $\mathrm{J}_{6}$ & $\mathrm{~J}_{7}, \mathrm{~J}_{8}, \mathrm{~J}_{9}$ & & $\mathrm{~J}_{4}$ & $\mathrm{~J}_{1}$ to $\mathrm{J}_{6}$ & $\mathrm{~J}_{7}, \mathrm{~J}_{8}, \mathrm{~J}_{9}$ \\
$\mathrm{~J}_{5}$ & $\mathrm{~J}_{5}$ & $\mathrm{~J}_{1}$ to $\mathrm{J}_{6}$ & $\mathrm{~J}_{7}, \mathrm{~J}_{8}, \mathrm{~J}_{9}$ & & $\mathrm{~J}_{5}$ & $\mathrm{~J}_{1}$ to $\mathrm{J}_{6}$ & $\mathrm{~J}_{7}, \mathrm{~J}_{8}, \mathrm{~J}_{9}$ \\
$\mathrm{~J}_{6}$ & $\mathrm{~J}_{5}$ & $\mathrm{~J}_{1}$ to $\mathrm{J}_{6}$ & $\mathrm{~J}_{7}, \mathrm{~J}_{8}, \mathrm{~J}_{9}$ & & $\mathrm{~J}_{6}$ & $\mathrm{~J}_{1}$ to $\mathrm{J}_{7}$ & $\mathrm{~J}_{8}, \mathrm{~J}_{9}$ \\
$\mathrm{~J}_{7}$ & $\mathrm{~J}_{5}$ & $\mathrm{~J}_{1}$ to $\mathrm{J}_{6}$ & $\mathrm{~J}_{7}, \mathrm{~J}_{8}, \mathrm{~J}_{9}$ & & $\mathrm{~J}_{7}$ & $\mathrm{~J}_{1}$ to $\mathrm{J}_{7}$ & $\mathrm{~J}_{8}, \mathrm{~J}_{9}$ \\
\hline
\end{tabular}

${ }^{1}$ Joining could be in the form of either joining the majority opinion or writing or signing a regular concurrence.

${ }^{2}$ Dissenting could be in the form of either writing or signing a formal dissent or writing or signing a special concurrence.

$\mathrm{J}_{5}$, but worse than $\mathrm{SQ}$ for Justices $\mathrm{J}_{6}, \mathrm{~J}_{7}, \mathrm{~J}_{8}$, and $\mathrm{J}_{9}$. Because Justices $\mathrm{J}_{6}$ and $\mathrm{J}_{7}$ want to move policy from SQ toward the left, but not as far as the policy at *, Justice $\mathrm{J}_{7}$ (for example) might draft a counteropinion at, say, $\mathrm{J}_{7}$. This counteropinion at $J_{7}$ is closer to the median justice's ideal point at $\mathrm{J}_{5}$ than is the draft majority opinion at ${ }^{*}$ and thus would gain her support: the policy at * lies outside $\mathrm{W}_{\mathrm{J} 5}\left(\mathrm{~J}_{7}\right)$; that is, outside the set of policies that the median justice prefers to the counteropinion at $\mathrm{J}_{7}$. In response, Justice $\mathrm{J}_{1}$ might write a counter-counteropinion at $\mathrm{J}_{4}$, for example, which is designed to win back the support of the median justice: note that $\mathrm{J}_{7}$ lies outside the $\mathrm{W}_{\mathrm{J} 5}\left(\mathrm{~J}_{4}\right)$ preferred-to set, which means that $\mathrm{J}_{4}$ is closer to $\mathrm{J}_{5}$ than is $\mathrm{J}_{7}$. This process would continue until the opinions converge on $\mathrm{J}_{5}$, the median justice's ideal point.

With a majority opinion now located at $\mathrm{J}_{5}$ in Figure 1 , Justice $J_{5}$ would of course support this opinion. The justices to the left of $\mathrm{J}_{5}$-that is, Justices $\mathrm{J}_{1}, \mathrm{~J}_{2}, \mathrm{~J}_{3}$, and $\mathrm{J}_{4}$ would all support this opinion at $J_{5}$ as well: for these justices, the policy at $\mathrm{J}_{5}$ lies inside their preferred-to sets of $S Q$. Moreover, the opinion at $J_{5}$ would also lie inside the preferred-to set of Justice $J_{6}$. Thus, this opinion at $J_{5}$ would gain the support of six justices $\left(\mathrm{J}_{1}\right.$ through $\left.\mathrm{J}_{6}\right)$, but it would be opposed by three justices $\left(J_{7}\right.$ through $J_{9}$ ), yielding a $6-3$ final vote.

Table 1 summarizes the inferences about two models that can be derived from the Figure 1 configuration of ideal points and the SQ. Because both models are based upon the premise that the majority opinion author and the bench median end up joining the majority, Figure 1 illustrates that the actions of the other justices can be used to infer whether the location of the final opinion is dictated by a strategic author or by the bench median. Of course, regardless of who writes the majority opinion, the outcomes under the bench median model are the same. The table also demonstrates that if either Justice $\mathrm{J}_{4}$ or $\mathrm{J}_{5}$ is assigned to write the opinion, the voting alignments will again be identical under both models. But for the configuration in Figure 1, a critical distinction involves the behavior of Justices $\mathrm{J}_{6}$ and $\mathrm{J}_{7}$ : it is whether Justices $\mathrm{J}_{6}$ and $\mathrm{J}_{7}$ join the majority opinion that will ultimately allow us to distinguish the impacts of the two models. ${ }^{7}$

To illustrate, note that if Justice $\mathrm{J}_{6}$ joins the majority when the author is Justice $J_{3}$, we can conclude that the bench median model was operative. The reason is that under the agenda control model, author $\mathrm{J}_{3}$ 's opinion would have been at *, which is worse for Justice $\mathrm{J}_{6}$ than $\mathrm{SQ}$, hence Justice $\mathrm{J}_{6}$ would not have joined the majority. ${ }^{8}$ Instead, the bench median model must have been operative, and the draft majority opinion must have been forced

${ }^{7}$ Every justice on the majority's side of SQ and outside $\mathrm{J}_{\text {med }}$ 's preferred-to set, $\mathrm{W}_{\text {Jmed }}(\mathrm{SQ})$, will have a preferred-to set that includes every point acceptable to the median justice. Thus, the median member of the majority coalition - the MMC - will automatically prefer to the SQ those outcomes that are derived from both the bench median and the agenda control models. For example, in Figure 1, the SQ is located between Justice $\mathrm{J}_{7}$ and Justice $\mathrm{J}_{8}$ and the MMC is Justice $\mathrm{J}_{4}$. Justice $\mathrm{J}_{4}$ never finds the outcome favored by the majority to be less desirable than the SQ. Likewise, both the agenda control and the bench median models imply that no justice who can conceivably be the median member of the majority coalition (Justices $J_{3}, J_{4}$, or $J_{5}$, in Figure 1) would oppose the position favored by the majority of the bench. The fact that the MMC model often leads to empirical outcomes that are consistent with both the bench median and agenda control models makes it very difficult to use voting data to test claims that the MMC is able to dictate the content of opinions.

${ }^{8}$ Note that we have been assuming that the majority opinion writer does only the bare minimum to gain the support of a Court majority. However, it has often been remarked that justices sometimes try to construct coalitions that are larger than absolutely necessary (e.g., as with Brown v. Board of Education). Since we have no way of knowing when an opinion writer will try to gain an "oversized" (i.e., larger than absolutely necessary) coalition, we ignore this possibility and test the prediction that opinion writers try only to get the support that is necessary for a policy as close as possible to their ideal points. This biases our results against our hypotheses. 
to $\mathrm{J}_{5}$, thereby accounting for Justice $\mathrm{J}_{6}$ 's support. In contrast, when the opinion author is Justice $\mathrm{J}_{6}$, observe that if Justice $\mathrm{J}_{7}$ joins the majority it implies that the agenda control model was operative; under the median model, the outcome would be at $\mathrm{J}_{5}$, but $\mathrm{J}_{5}$ lies outside Justice $\mathrm{J}_{7}$ 's preferred-to set. What is important here is that for every possible configuration of SQ and the justices' ideal points, we can make similar inferences, based on each model, about the expected behavior of the justices.

From the agenda control model we can thus derive the following testable hypothesis:

The Agenda Control Hypothesis: A justice's support for the majority opinion depends on whether he or she considers the point that is closest to the opinion author and that lies inside or on the boundary of the median justice's preferred-to set to be at least as good as SQ.

Formally, the agenda control model assumes that a justice will join the majority opinion if $\left|X_{j}-X_{o p}\right| \leq \mid X_{j}$ $-S Q \mid$, where $X_{j}$ is the location of the ideal point of the $\mathrm{j}^{\text {th }}$ justice who is not the median justice, and $\mathrm{X}_{\mathrm{op}}$ is the location of the majority opinion author's draft opinion. If the majority opinion author's ideal point lies outside $\mathrm{W}_{\text {Jmed }}(\mathrm{SQ}), \mathrm{X}_{\mathrm{op}}$ will be the point, *, that is at the outside (away from $\mathrm{SQ}$ ) boundary of $\mathrm{W}_{\text {Jmed }}(\mathrm{SQ})$; if the opinion author's ideal point lies inside $\mathrm{W}_{\text {Jmed }}(\mathrm{SQ}), \mathrm{X}_{\mathrm{op}}$ will be at the author's ideal point.

And from the bench median model we can derive the following testable hypothesis:

The Bench Median Hypothesis: A justice's support for the majority opinion depends on whether he or she considers the median justice's ideal point to be at least as good as SQ.

Formally, this model assumes that a justice will join the majority opinion if $\left|X_{j}-X_{\text {med }}\right| \leq\left|X_{j}-S Q\right|$, where $X_{\text {med }}$ is the location of the median justice's ideal point and $X_{j}$ is the location of the ideal point of the $\mathrm{j}^{\text {th }}$ justice who is not the median justice.

\section{Measures and Data}

To ascertain whether the agenda control or bench median model best characterizes Supreme Court decision making, we examine each justice's decision to join the majority opinion for every case for which a majority opinion was released during the Burger Court (1969-86). Because the bench median and the agenda control models imply that different justices may join the majority, we infer who controls the final opinion based upon who joins. To test the two models we need a proxy for the location of each justice's ideal point and for the location of the status quo.

Estimating the Ideal Points. As a measure of judicial ideology, we calculate the percentage of cases in which each justice voted in a liberal direction for each Spaeth (2001) value area of a case in the term prior to the one in which the case was decided. ${ }^{9}$ Given this measure, we calculate each justice's ideological distance from the Court median. Although the proportion of the time a justice votes in a liberal direction has several desirable properties as a measure of ideology, ${ }^{10}$ it also has a potentially serious flaw: the measure fails to take into account the constraints that structure a justice's inclination to vote in a liberal or conservative direction. Most importantly, it fails to take into account how changes in the Court's agenda might affect a justice's voting history. Hence, we also employ the ideological ratings that Martin and Quinn (2002) computed via a Bayesian Markov Chain Monte Carlo procedure that accounts for temporal constraints that may bias a measure based simply upon the proportion of the time a justice votes in a particular direction. ${ }^{11}$

Estimating the Status Quo Policy. To construct a measure of the status quo, we identify SQ as the midpoint between two justices, one of whom votes for cert and one of whom votes to deny. We first identify the justice who is most likely to agree with the lower court but who also supports cert. We then identify the justice who is closest to this justice, who voted to deny cert, and who is closest to the lower court ruling. The direction of the lower court

${ }^{9}$ Cases are assigned to 13 substantive "value" (i.e., broad issue) areas, such as federalism and criminal process. One area is "miscellaneous." Cases in this category were dropped. If a case raised more than one value, we took the mean of the justice's ideology in the value areas. Since our variable is based on prior voting, we lack an ideology measure for a justice's first term. For these justices, we rely upon the Johnson, Spriggs, and Wahlbeck (2005) estimates.

${ }^{10}$ This measure has three desirable properties. First, it has been commonly used and validated (Maltzman, Spriggs, and Wahlbeck 2000; Rohde and Spaeth 1976; Segal and Spaeth 2002). Second, it recognizes that distinct ideological dimensions may characterize different areas. Third, by yearly updating the measure ideological shifts that occur during a justice's tenure are taken into account.

\footnotetext{
${ }^{11}$ Because the results using both ideology measures are nearly identical, the reports in the descriptive tables (Tables 2 and 3 ) are based on just the first measure. In Table 4 we run models using both measures of ideology. Although the Martin and Quinn (2002) measure is not issue specific, it does a very good job of predicting the voting behavior of justices in civil liberties and civil rights cases. Although the scores do not perform as well in other areas, they tend to perform better than do other nonissue-specific ideological measures.
} 


\section{FIGURE 2 Illustrating the Procedure for Estimating the Location of SQ, Given the Certiorari Vote (Assuming the Lower Court Ruled in a "Liberal" Direction in This Case)}

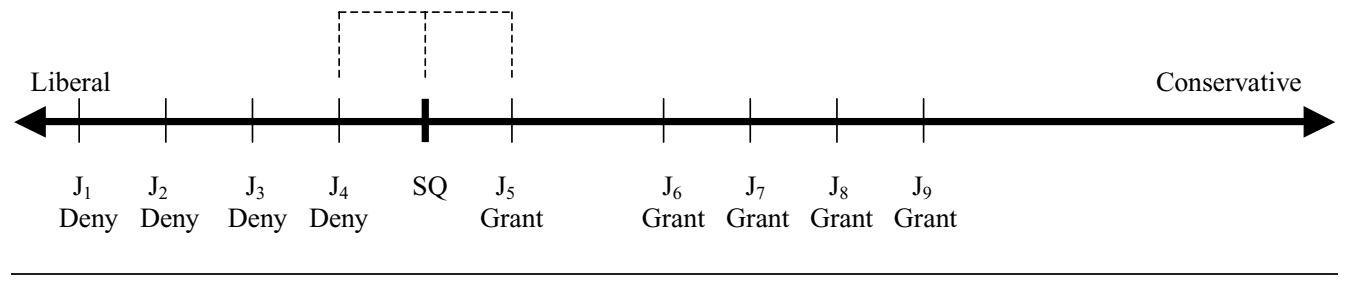

ruling is based upon Spaeth (2001). We assume that SQ is located at the midpoint between these two justices. ${ }^{12}$

Given a liberal lower court ruling, we estimate the location of SQ in three steps. First, we identify the most liberal justice who nonetheless supports a grant of certiorari. In Figure 2, this is Justice $\mathrm{J}_{5}$. In spite of this justice's liberal-leaning predisposition, it seems reasonable to think that this justice does not like this lower court ruling and is, in fact, the liberal justice who is the closest to SQ. Second, we identify the justice who is next to this liberal justice, who voted to deny cert, and whose ideal point is on the liberal side of the first justice. This is Justice $\mathrm{J}_{4}$ in Figure 2. Third, we assume that SQ is located at the midpoint between these two justices. ${ }^{13}$ For a "conserva-

${ }^{12}$ If the entire bench voted in favor of cert, we located the status quo as the midpoint between the most extreme justice who was on the same side of the bench as the lower court and the endpoint of the ideological scale ( 0 for a conservative lower court ruling and 1 for a liberal lower court).

${ }^{13}$ Even though a justice who is normally sympathetic to the lower court ruling, but seeks to reverse, is unlikely to be at SQ, he is nonetheless likely to be closer than a justice who is normally hostile to the position embraced by the lower court. And a justice who votes to deny cert is more likely to approve of the SQ than a justice who supports cert. Hence, it seems reasonable to conjecture that the SQ will fall between these two justices. Our use of the cert vote as a measure of the status quo is based upon the assumption that an error correction strategy drives cert votes. Recently, Caldeira, Wright, and Zorn (1999) and Benesh, Brenner, and Spaeth (2002) have made the case that strategic decisions may drive cert voting. According to this view, a justice takes into account the likely final location of a majority opinion prior to casting a cert vote. If one goes back to Figure 1, this might mean that even though the true location of the SQ is $\mathrm{J}_{9}, \mathrm{~J}_{7}$ and $\mathrm{J}_{8}$ might vote against cert if they believe the final opinion will be located at either $\mathrm{J}_{5}$ or ${ }^{*}$. We would then misidentify the cert location as the midpoint between $\mathrm{J}_{6}$ and $\mathrm{J}_{7}$. To the extent that strategic cert votes occur, we are stacking the deck against our model that suggests that a justice's decision to join the majority depends upon whether the final outcome (either* or $\mathrm{J}_{5}$ ) or the SQ is closer to their ideal point. The fact that we find the relative distance between each justice's ideal point and both the SQ and the final outcome (either * or $\mathrm{J}_{5}$ ) to be significant gives us even more faith in our measure of the SQ and our conclusion that a justice evaluates an opinion relative to the SQ. tive" lower court ruling, the logic is the same though the directions are reversed.

The justification for this measure rests upon two related facts. ${ }^{14}$ First, we know (and the justices themselves would know) that for any case the policies produced by both the agenda control and bench median models will lie on the same side of the status quo. At least five justices on the majority side of the status quo-always including the median justice, $\mathrm{J}_{\mathrm{med}}$, and the other four justices with ideal points on the side of $\mathrm{J}_{\text {med }}$ away from SQ-will always have an incentive to support certiorari: they know policy will move in the direction of their ideal points if the Court hears this case. Second, as a result, these justices tend to support certiorari when interested in reversing or otherwise altering a decision of the lower court; justices are less likely to support certiorari when they support a lower court ruling (Caldeira and Wright 1988; Epstein and Knight 1998).

The Test. We can now describe how we construct our tests. If the agenda control model accurately accounts for who controls the majority opinion, we would expect the opinion to be crafted as close as possible to the author's ideal point but within or on the border of the Court median's preferred-to set. To identify this preferred-to set, we determine the distance between the median justice's ideal point and the status quo measure, and then we double this distance (to account for the half of $\mathrm{W}_{\mathrm{J5}}(\mathrm{SQ})$ on the side of $\mathrm{J}_{5}$ away from $\mathrm{SQ}$ ). Any opinion closer to $\mathrm{SQ}$ than this overall distance is considered to lie inside the median justice's preferred-to set, and the opinion author will locate his or her opinion inside (or on the border of) this preferred-to set.

If the opinion author's ideal point is found to lie inside or on the border of the median justice's preferred-to set, $\mathrm{W}_{\mathrm{I5}}(\mathrm{SQ})$, the agenda control model leads us to predict that the opinion will be written at the author's ideal point. Using our empirical measures we calculate that the

\footnotetext{
${ }^{14}$ Examples of our measure and a more detailed discussion of it are included in the appendix discussed in footnote 5.
} 
opinion should have been written at the author's ideal point in $72.8 \%$ of the cases $(1,722$ out of 2,389$)$ in our sample. If the opinion author's ideology score suggests that he would most prefer an outcome that falls to the left of the median justice's preferred-to set, $\mathrm{W}_{\mathrm{J} 5}(\mathrm{SQ})$, we assume that the opinion should have been written at the lefthand boundary of $\mathrm{W}_{\mathrm{J} 5}(\mathrm{SQ})$, whereas if the opinion author and Court median are to the right of SQ, and if the author's ideal point falls to the right of $\mathrm{W}_{\mathrm{J} 5}(\mathrm{SQ})$, we assume the opinion should have been written at the right-hand boundary of $\mathrm{W}_{\mathrm{J} 5}(\mathrm{SQ})$. Using our empirical measures we calculate that the opinion should have been written at the left-hand or right-hand boundary of the median justice's preferred-to set in $20.6 \%$ of the cases (492 of 2,389). Finally, we calculate that the opinion author is located on the opposite side of SQ from the justice we identify as the median in $7.3 \%$ of our cases (174 of 2,389). In these instances, we place the opinion where SQ itself is located; for these cases we presume that the case outcome reaffirms SQ. (These three percentages sum to slightly more than $100 \%$ because the categories are not entirely mutually exclusive due to cases in which an opinion author's ideal point lies exactly on a boundary of $\mathrm{W}_{\mathrm{I} 5}(\mathrm{SQ})$.)

To test how well each model predicts the justices' votes on these opinions, we create a dummy variable for each model, based on our measures for the status quo and the justices' ideal points. The first dummy variable, AUTHOR ACCEPTABILITY, is used in testing the agenda control model. It indicates whether a justice has an ideology score that is closer to the policy that the opinion author would select than to SQ. In Figure 1, for example, if Justice $J_{1}, J_{2}$, or $\mathrm{J}_{3}$ was the author and so would be expected to locate the opinion at * on the left-hand border of $\mathrm{W}_{\mathrm{J} 5}(\mathrm{SQ})$, we would give Justices $\mathrm{J}_{1}$ through $\mathrm{J}_{5}$ a 1 and give Justices $\mathrm{J}_{6}$ through $\mathrm{J}_{9}$ a 0 . If the agenda control model accurately accounts for what happens on the Court and if Justice $\mathrm{J}_{1}, \mathrm{~J}_{2}$, or $\mathrm{J}_{3}$ is the author, we would expect Justices $\mathrm{J}_{1}$ through $\mathrm{J}_{5}$, for whom AUTHOR ACCEPTABILITY $=1$, to actually support the majority opinion that Justices $\mathrm{J}_{1}, \mathrm{~J}_{2}$, and $\mathrm{J}_{3}$ would produce.

We also create a second dummy variable, MEDIAN ACCEPTABILITY, to denote those instances in which a justice is closer to the bench median than to the status quo. In Figure 1 , for example, Justices $J_{1}$ through $J_{6}$ would be given a 1 for MEDIAN ACCEPTABILITY since they should prefer $J_{5}$, Justice $J_{5}$ 's most preferred policy, to SQ. In contrast, Justices $\mathrm{J}_{7}$ through $\mathrm{J}_{9}$ would be given a 0 for MEDIAN ACCEPTABILITY since they would withhold their vote from the majority opinion. If the bench median model accurately accounts for what happens on the Court, we would expect that, no matter who the opinion author is, the justices for whom MEDIAN ACCEPTABILITY $=1$ will support the majority opinion at $\mathrm{J}_{5}$.

For each model, the key question is whether the justices who are predicted to join the majority opinion actually do so at a higher rate than those predicted not to join the majority opinion.

\section{Results}

We analyze the 18,419 votes that were cast by individual justices, excluding the majority opinion author, in 2,389 cases from 1971 to 1985 . Overall, $77.8 \%$ of these votes supported the majority opinion. ${ }^{15}$ The first column in Table 2 highlights the relationship between our independent variables (AUTHOR ACCEPTABILITY and MEDIAN ACCEPTABILITY) and the dependent variable (did the justices support the majority opinion?). For the agenda control model, we expected that the justices for whom AUTHOR ACCEPTABILITY $=1$ would support the majority opinion at a significantly higher rate than the justices for whom AUTHOR ACCEPTABILITY $=0$. For the bench median model, we expected that the justices for whom MEDIAN ACCEPTABILITY $=1$ would support the majority opinion at a significantly higher rate than the justices for whom MEDIAN ACCEPTABILITY $=0$.

For the agenda control model, Table 2 shows that $83.6 \%$ of the justices who were closer to the majority author's opinion than to the status quo (AUTHOR ACCEPTABILITY $=1$ ) actually joined the majority. In contrast, only $68.2 \%$ of the justices who were closer to the status quo than to the author's opinion (AUTHOR ACCEPTABILITY = 0 ) actually joined the majority opinion. This difference is even larger if we eliminate cases where the Court was unanimous. Whereas $73.7 \%$ of the justices for whom AUTHOR ACCEPTABILITY $=1$ on nonunanimous cases actually joined the majority, only $53.6 \%$ of the justices for whom AUTHOR ACCEPTABILITY $=0$ on these cases actually joined the majority opinion. These patterns lend some credence to the agenda control model.

\footnotetext{
${ }^{15}$ We have excluded observations associated with cases where there is no author (e.g., a per curiam opinion) or where Spaeth (2001) does not report a cert vote or the direction of the lower court ruling. In all our calculations, regular concurrences are treated as "joining" the majority opinion, while special concurrences are treated as "dissents." Our rationale should be clear: a justice writing or signing a regular concurrence is agreeing with majority opinion but has some additional comments to make, whereas a justice writing or signing a special concurrence is agreeing with the case disposition (affirming or reversing the lower court's decision) but is disagreeing with reasons set forth in the majority opinion.
} 


\section{TABLE 2 Do the Expected Justices Join the Majority Opinion?}

\begin{tabular}{lcc}
\hline & $\begin{array}{c}\text { All Burger } \\
\text { Court } \\
\text { Cases }^{1}\end{array}$ & $\begin{array}{c}\text { Nonunanimous } \\
\text { Burger } \\
\text { Court Cases }^{2}\end{array}$ \\
\hline Overall & $77.8 \%$ & $65.6 \%$ \\
Author acceptability $=1$ & $83.6 \%$ & $73.7 \%$ \\
Author acceptability $=0$ & $68.2 \%$ & $53.6 \%$ \\
Difference & $15.4^{* * *}$ & $20.1^{* * *}$ \\
Median acceptability $=1$ & $81.5 \%$ & $70.6 \%$ \\
Median acceptability $=0$ & $67.9 \%$ & $53.5 \%$ \\
Difference & $13.6^{* * *}$ & $17.1^{* * *}$ \\
N & $18,419^{3}$ & $11,872^{3}$ \\
\hline
\end{tabular}

${ }^{* * *} \mathrm{p}<.001$.

${ }^{1}$ The 18,419 votes included in our analysis are spread over 2,389 cases.

${ }^{2}$ The 11,872 nonunanimous votes included in our analysis are spread over 1,530 cases.

${ }^{3}$ The opinion author is excluded from these tabulations.

For the bench median model, Table 2 shows that $81.5 \%$ of the justices who were closer to the median justice than to the status quo (MEDIAN ACCEPTABILITY $=1$ ) actually joined the majority opinion. In contrast, only $67.9 \%$ of the justices who were closer to the status quo than to the median (MEDIAN ACCEPTABILITY $=0$ ) actually joined the majority opinion. As before, this difference becomes even larger if we drop the unanimous cases. Whereas $70.6 \%$ of the justices who were closer to the median than to the SQ on nonunanimous cases (MEDIAN ACCEPTABILITY $=1$ ) actually joined the majority opinion, only $53.5 \%$ of the justices who were closer to the SQ than to the median on these nonunanimous cases (MEDIAN ACCEPTABILITY $=0$ ) actually joined the majority opinion. These patterns lend some credence to the bench median model.

Thus, both models have some empirical support, which demonstrates the importance of the status quo in the justices' decisions on joining the majority. But the fact that Table 2 supports both models illustrates the difficulty of distinguishing the two models. Indeed, if the justices' preferences on the cases in our dataset resembled those in Figure 1 and if Justice $\mathrm{J}_{1}, \mathrm{~J}_{2}, \mathrm{~J}_{3}, \mathrm{~J}_{4}$, or $\mathrm{J}_{5}$ were the author, we would expect these five justices to vote the same under both models; the only justices in Figure 1 whose actions would be different in the two models are Justice $\mathrm{J}_{6}$ when Justice $\mathrm{J}_{1}, \mathrm{~J}_{2}$, or $\mathrm{J}_{3}$ is the author and Justice $\mathrm{J}_{7}$ when Justice $\mathrm{J}_{6}$ or $\mathrm{J}_{7}$ is the author.

In Table 3 we examine only those justices whose ideal points (a) were closer to the point where a rational author would locate an opinion than to the status quo, but
TABLe 3 Do the Expected Justices Join the Majority Opinion (Key Justices Only; All Cases)?

\begin{tabular}{lcc}
\hline & Number of Votes & Proportion $^{\mathbf{1}}$ \\
\hline Author acceptability & 1 \& median acceptability & 0 \\
Join Majority & 283 & $84.7 \%$ \\
Don't Join & 51 & $15.3 \%$ \\
Total & 334 & $100.0 \%$ \\
Median acceptability & 1 \& author acceptability $=0$ \\
Join Majority & 1,604 & $71.3 \%$ \\
Don't Join & 645 & $28.7 \%$ \\
Total & 2,249 & $100.0 \%$ \\
\hline
\end{tabular}

${ }^{1}$ The opinion author is excluded from these tabulations.

not closer to the median than to the status quo, and (b) those justices whose ideal points were closer to the median than to the status quo, but not closer to the point where a rational author would locate an opinion than to the status quo. Of the 18,419 individual votes in our dataset, only 2,583 votes can be used to differentiate between the agenda control and bench median models in the way that is indicated here. When these justices were closer to the point where a rational author would locate the opinion than to the SQ, but not closer to the median justice than to the status quo, the justices joined the majority $84.7 \%$ of the time. In contrast, when these justices were closer to the median than the SQ, but not closer to the point where a rational author would place the opinion than to the SQ, the justices joined the majority less frequently, only $71.3 \%$ of the time. (The difference between these two scenarios is significant at the $\mathrm{p}<.001$ level.) The behavior of these justices suggests that the agenda control model does better than does the bench median model.

Even stronger inferences can be drawn from pitting the bench median and agenda control models directly against each other. We employ a nonnested hypothesistesting approach (Clarke 2001). This approach is appropriate for two reasons. First, each of our models employs a unique covariate. Whereas the agenda control model suggests that a justice's decision to support the majority opinion depends on the justice's preferences for the policy at $\mathrm{X}_{\mathrm{op}}$ relative to the status quo, the bench median model posits that a justice's decision to support the majority opinion depends on the justice's preference for the median's ideal point relative to the status quo. ${ }^{16}$ Neither

\footnotetext{
${ }^{16}$ Recall that $\mathrm{X}_{\mathrm{op}}$ is a policy at * when the author's ideal point is outside $\mathrm{W}_{\text {Jmed }}(\mathrm{SQ})$, and a policy at the author's ideal point when this ideal point is inside $\mathrm{W}_{\text {Jmed }}(\mathrm{SQ})$.
} 


\section{TABLE 4 Logit Estimates of the Probability of Joining the Majority Coalition}

\begin{tabular}{|c|c|c|c|c|}
\hline & \multicolumn{2}{|c|}{$\begin{array}{c}\text { Percent Liberal Issue-Specific } \\
\text { Ideology Measure }\end{array}$} & \multicolumn{2}{|c|}{$\begin{array}{c}\text { Martin-Quinn } \\
\text { Ideology Measure }\end{array}$} \\
\hline & $\begin{array}{c}\text { Agenda Control } \\
\text { Model }\end{array}$ & $\begin{array}{c}\text { Bench Median } \\
\text { Model }\end{array}$ & $\begin{array}{c}\text { Agenda Control } \\
\text { Model }\end{array}$ & $\begin{array}{c}\text { Bench Median } \\
\text { Model }\end{array}$ \\
\hline Author acceptability & $\begin{array}{l}.863^{* * *} \\
(.050)\end{array}$ & - & $\begin{array}{l}.738^{* * *} \\
(.041)\end{array}$ & - \\
\hline Median acceptability & - & $\begin{array}{l}.730^{* * *} \\
(.054)\end{array}$ & - & $\begin{array}{l}.764^{* * *} \\
(.054)\end{array}$ \\
\hline Constant & $\begin{array}{l}.764^{* * *} \\
(.035)\end{array}$ & $\begin{array}{l}.751^{* * *} \\
(.041)\end{array}$ & $\begin{array}{l}.880^{* * *} \\
(.030)\end{array}$ & $\begin{array}{l}.724^{* * *} \\
(.042)\end{array}$ \\
\hline Observations & 18,419 & 18,419 & 18,419 & 18,419 \\
\hline $\mathrm{BIC}^{\prime}$ & -567.098 & -360.772 & -417.496 & -392.494 \\
\hline
\end{tabular}

*** $\mathrm{p}<.001$. Robust standard errors were employed (clustered on the case) and are reported in parentheses.

The difference of 206.326 (using the percent-liberal measure) in the $\mathrm{BIC}^{\prime}$ provides very strong support for the agenda control model over the bench median model. The difference of 25.001 (using the Martin-Quinn measure) in the BIC' provides very strong support for the agenda control model over the bench median model.

model holds that a justice's decision to join the majority is conditioned upon a justice's relative location to both the policy at* and the median justice's ideal point. If we followed the common practice of allowing for a "race among the variables" in a single equation, the result would be an equation without theoretical grounding. ${ }^{17}$ Second, our two independent variables (AUTHOR ACCEPTABILITY and MEDIAN ACCEPTABILITY) have similar, albeit not identical, components. As a result, if we artificially nested the models, our results could be affected by collinearity. ${ }^{18}$

Table 4 evaluates the two models, showing the effect that a rational opinion author (columns 1 and 3 ) and the median justice (columns 2 and 4 ) have on a justice's decision to join the majority opinion. The first two columns are based upon the independent variable calculated from the percent-liberal scores; the third and fourth columns are based upon the Martin-Quinn ideology scores. In both models we predict the probability that a justice will join the opinion. ${ }^{19}$

\footnotetext{
${ }^{17}$ Davidson and MacKinnon's $J$ test, as well as the Cox-Pesaran statistic, support our assumption that these models are nonnested (see Greene 1997, 364-69).

${ }^{18}$ The pairwise correlation between AUTHOR ACCEPTABILITY and MEDIAN ACCEPTABILITY is .67 $(\mathrm{p}<.001)$.

${ }^{19}$ Because our dependent variable is dichotomous, a logit model is the appropriate estimator. Since there are multiple votes in each case, it is possible that a residual for one justice's observation is correlated with another justice's in that case. To control for this, we employ a robust variance estimator clustering on each case. We also run the models by clustering on each justice and with fixed effects variables for each justice. These approaches yield identical conclusions. All of the models are based upon the full set of 18,419 individual votes that were cast.
}

As Table 4 shows, both models have substantial explanatory power: for both models the relevant nonnested independent variable is statistically significant. For the agenda control model, justices who were closer to the point where a rational author would craft the majority than to the status quo were more likely to support the majority. For the bench median model, justices who were ideologically closer to the median justice than to the status quo were more likely to join the majority. These findings reflect the fact that justices' behavior is often identical under both models. Indeed, both models lead one to expect the median to join the final opinion.

To ascertain which model is better, we use the Bayesian Information Criterion (BIC). The BIC compares two nonnested models by looking at the Bayes Factor, which reduces to the ratio of posterior odds. The BIC is an efficient mechanism for comparing nonnested models by comparing the probability that each model is the true model given the observed data (Clarke 2001; Kuha 2004) ${ }^{20}$ If one assumes that other variables included in a fully specified model of what might influence an individual justice's decision to join (e.g., the salience of the case) should not vary across the models in contention, the BIC is valuable for discriminating across models.

The objective when selecting models is to minimize the BIC: the best model will be the one with the smallest

\footnotetext{
${ }^{20} \mathrm{An}$ alternate measure of model selection is Akaike's information criterion (AIC), which varies in what it considers a good model. While the BIC identifies "models with the highest probabilities of being the true model for the data," the AIC uses "expected prediction of future data" as the criterion of models (Kuha 2004, 216-17). Here, the AIC favors the same model as the BIC.
} 


\section{TABLE 5 Random Effects Logit Estimates of the Probability of Joining the Majority Coalition}

\begin{tabular}{|c|c|c|}
\hline & Agenda Control & Bench Median \\
\hline \multicolumn{3}{|l|}{ Agenda Control Variables } \\
\hline AUTHOR ACCEPTABILITY & $\begin{array}{l}1.083^{* * *} \\
(.049)\end{array}$ & - \\
\hline AUTHOR ACCEPTABILITY $\times$ FRESHMAN & $\begin{array}{r}-.408^{*} \\
(.182)\end{array}$ & - \\
\hline AUTHOR ACCEPTABILITY $\times$ COMPLEXITY & .050 & \\
\hline AUTHOR ACCEPTABILITY $\times$ SALIENCE & $\begin{array}{l}.114^{* *} \\
(.041)\end{array}$ & - \\
\hline AUTHOR ACCEPTABILITY $\times$ CJ & $\frac{.223}{(.141)}$ & - \\
\hline \multicolumn{3}{|l|}{ Median Control Variables } \\
\hline MEDIAN ACCEPTABILITY & - & $\begin{array}{l}.920^{* * *} \\
(.047)\end{array}$ \\
\hline MEDIAN ACCEPTABILITY $\times$ FRESHMAN & - & $\begin{array}{l}-.741^{* * *} \\
(.190)\end{array}$ \\
\hline MEDIAN ACCEPTABILITY $\times$ COMPLEXITY & - & $\frac{-.071}{(.048)}$ \\
\hline MEDIAN ACCEPTABILITY $\times$ SALIENCE & - & $\begin{array}{l}.106^{* *} \\
(.040)\end{array}$ \\
\hline MEDIAN ACCEPTABILITY $\times$ CJ & - & $\frac{-.442^{* *}}{(.150)}$ \\
\hline \multicolumn{3}{|l|}{ Control Variables } \\
\hline FRESHMAN & $\begin{array}{l}.533^{* * *} \\
(.134)\end{array}$ & $\begin{array}{l}.820^{* * *} \\
(.156)\end{array}$ \\
\hline COMPLEXITY & $\begin{array}{l}-.325^{* * *} \\
(.042)\end{array}$ & $\begin{array}{l}-.252^{* * *} \\
(.046)\end{array}$ \\
\hline SALIENCE & $\begin{array}{l}-.137^{* * *} \\
(.035)\end{array}$ & $\begin{array}{l}-.138^{* * *} \\
(.037)\end{array}$ \\
\hline CJ & $\begin{array}{l}.456^{* * *} \\
(.101)\end{array}$ & $\begin{array}{l}.907^{* * *} \\
(.124)\end{array}$ \\
\hline CONSTANT & $\begin{array}{l}.864^{* * *} \\
(.041)\end{array}$ & $\begin{array}{l}.830^{* * *} \\
(.044)\end{array}$ \\
\hline Observations & 18,419 & 18,419 \\
\hline Chi-SQ & $754.26^{* * *}$ & $583.13^{* * *}$ \\
\hline $\ln \left(\sigma_{\mathrm{v}}\right)$ & $\begin{array}{c}.006 \\
(.074)\end{array}$ & $\begin{array}{r}-.095 \\
(.077)\end{array}$ \\
\hline$\sigma_{\mathrm{v}}$ & $\begin{array}{l}1.003 \\
(.037)\end{array}$ & $\begin{array}{c}.954 \\
(.037)\end{array}$ \\
\hline$\rho$ & $\begin{array}{l}.234 \\
(.013)\end{array}$ & $\begin{array}{l}.217 \\
(.013)\end{array}$ \\
\hline Likelihood ratio test of $\rho=0$ & $561.12^{* * *}$ & $505.84^{* * *}$ \\
\hline $\mathrm{BIC}^{\prime}$ & -1297.186 & -1053.882 \\
\hline
\end{tabular}


(most negative) value of the BIC statistic (Long and Freese 2006, 112). The bottom row in Table 4 shows that a justice's proximity to the point where a rational author would craft the majority opinion relative to the status quo (AUTHOR ACCEPTABILITY) is a better predictor of a justice's decision to join the majority opinion than a justice's proximity to the median justice relative to the status quo (MEDIAN ACCEPTABILITY). Regardless of whether one utilizes issuespecific or Martin-Quinn ideology scores, the agenda control model fits better.

Nevertheless, it is important to note that in Table 4, the independent variable in both models is statistically significant. In other words, there is ample evidence that both the justices' relative proximity to the chamber median and the status quo and their proximity to the point where a strategic author is likely to locate the majority opinion and the status quo matter. Inevitably, this pattern reflects the fact that for many justices the two models are observationally equivalent. The pattern also highlights the value that is gleaned by incorporating an understanding of the location of the status quo. Even with a measure of the status quo that inevitably includes some measurement error, a justice's decision to join the majority stems in part from his or her belief as to whether the final outcome represents an improvement in the law.

Although Table 4 is valuable for discriminating between the two models, it is not a valuable tool for making a precise prediction about a justice's tendency to join the majority. Because our intention with the models in Table 4 is to use the behavior of the justices as a vehicle for inferring the relative value of the agenda control and median justice models, the abbreviated nonnested models are useful. Table 4 reaffirms what Tables 2 and 3 suggested: the majority opinion author can dictate the final opinion within a set of constraints established by what policies the median prefers to the status quo.

Nevertheless, it is reasonable to ask whether the value of the author and median acceptability variables holds when subject to various multivariate controls. In Table 5, we present two multivariate random-effects logit models of a justice's decision to join the majority. The model on the left interacts the AUTHOR ACCEPTABILITY variable with variables to tap whether the justice was the Chief Justice (CJ); whether the justice was new to the bench (FRESHMAN); and variables to tap the complexity (COMPLEXITY) and salience (SALIENCE) of a case. ${ }^{21}$ In the right-hand col-

\footnotetext{
${ }^{21}$ FRESHMAN is a dummy to denote any justice who has served less than two full years when the case was decided. CJ is a dummy to denote Chief Justice Burger. Case complexity was formed by combining three indicators, all of which were derived from Spaeth (2001). The first measure is the number of issues raised by the case. The second is the number of legal provisions relevant to a case. The
}

umn, we interact these same variables with the MEDIAN ACCEPTABILITY dummy variable. These interactions examine the conditions under which the key variables exhibit effects with greater or lesser strength.

A simple comparison of the shaded interactions variables in Table 5 is revealing. When we interact a dummy to denote the Chief Justice with the acceptability variables, we see a positive coefficient in the left-hand model and a negative coefficient on the right. These findings suggest that when it comes to Chief Justice Burger's decision to join the majority, he was more responsive to the author and less responsive to the median than his colleagues. Given that he disproportionately made the opinion assignments and the fact that, as Chief Justice, he may have felt that his institutional responsibilities precluded him from abandoning the assigned author, such a finding is not surprising. Likewise, the negative coefficient on the right for COMPLEXITY X MEDIAN ACCEPTABILITY suggests that when it comes to complex cases, the median is likely to exert less influence. Inevitably, this reflects in part the fact that it is more difficult for the median to pursue his or her preferences on a particularly complex case.

\section{Conclusion}

The judicial politics literature has long recognized that the power of the Supreme Court stems primarily from its capacity to influence, through its written opinions, the actions of Congress, the president, lower courts, interest groups, and the general public. Even so, this literature has yet to develop an adequate understanding of how and why the Court selects the content of its opinions. In recent years, the argument has been made that the majority opinion will be written at the ideal point of the Court's median justice. However, most judicial scholars have long assumed that the majority opinion author is a key agenda setter for the Court's decision-making process, and our

third is the number of opinions released in a case. Factor analysis of these three indicators produced a single factor with an eigenvalue of greater than one. We used each case's factor score as a measure of COMPLEXITY. As a measure of case salience, we create a variable that measures the relative number of amicus curiae briefs filed in every case. To calculate the number of amicus briefs, we relied upon Gibson (1997). Since amicus participation has increased over the time period under investigation, we calculate term-specific statistics, i.e., mean and standard deviation, and determine whether a case had more amici filings than the average case heard during a term. More specifically, we calculate a term-specific z-score for amicus participation. Once again, the BIC comparison of these two models supports the agenda control model. The Table 5 measures are based upon the percent-liberal ideology measure. A table comparable to Table 5, but based upon the Martin-Quinn scores is available in the appendix referenced in footnote 5 . 
empirical results suggest that there is substantial merit to this latter view. In general, it does not appear that the opinions are always at the median's ideal point; instead, the majority opinion author appears to retain some discretion over the location of the final opinion.

The fact that the majority opinion author appears to have some independent impact on the location of the final opinion justifies the attention that judicial politics scholars have given to the opinion assignment process: it matters who writes the opinion, hence it matters who is given the assignment in the first place. Indeed, the focus on the strategic behavior of the justices, initiated by Murphy (1964) and given renewed attention by Epstein and Knight (1998), Maltzman, Spriggs, and Wahlbeck (2000), and Hammond, Bonneau, and Sheehan (2005), is justified by the evidence on behalf of the agenda control model. After all, if the opinions always end up at the median justice's ideal point, there would be no reason for strategic behavior at any stage of the Court's decision-making process.

Nonetheless, while our results provide a rationale for research into questions long considered important by judicial politics scholars, this judicial politics research has not been based on a fully adequate theoretical foundation because, among other things, it has rarely incorporated the status quo in its analyses; without a concern for the status quo, it is not clear how a satisfactory understanding of the agenda control activities of the majority opinion author can be developed.

In fact, judicial politics scholars have often treated Supreme Court justices as acting in a context that is independent of the past. The justices' choices are frequently portrayed as reflecting little more than the preferences each justice brings to the decision-making process, perhaps considered in light of a variety of case facts; whatever happened previously with the law, including the establishment of precedents, is not given much emphasis. It is a portrait that is in stark contrast to at least two decades of research on another collegial decision-making bodythe U.S. Congress-where control of the rules allocating agenda control often allow pivotal legislators, such as party leaders, to protect the status quo, or to move policies away from it.

Although we are not in a position to challenge those who argue that the precedents established by the Supreme Court are not a constraint on the Court (Brenner and Spaeth 1995; Spaeth and Segal 1999), our empirical results clearly suggest that the status quo that is established by the lower courts, and that is often influenced by prior decisions of the Court, does play a role in shapingalthough not determining - the development of the law. Even though justices may not be bound by particular precedents, there is now reason to think that justices condition their decisions on whether they want the legal status quo to be changed or upheld.

Although our tests reveal something about the explanatory power of the agenda control model relative to that of the bench median model, both models perform reasonably well. While it is beyond the scope of this article, future work needs to distinguish what conditions might evoke one model rather than another. We suspect, for example, that the relative power of the models may vary when we control for the salience and complexity of the underlying cases. It is even possible that the nature of the personal relationship that exists between the majority opinion author and the median justice will influence whether one model has more explanatory power.

Even so, neither model performs perfectly: the votes of the justices cannot be fully explained by their ideal points' relationships to the status quo, to the location of the bench median, and to the point where a rational opinion author would place the opinion. Indeed, of the 18,419 judicial votes in our analysis, justices joined the majority 3,170 times (17.2\%) despite being closer to the location of the SQ point, as estimated here, than to the median justice or to the point at which we would expect a rational opinion author to locate the opinion. This failure on the models' part presumably might reflect a variety of factors, including measurement errors (for the justices' ideologies and for the status quo), strategic mistakes made by the justices in the decision-making process, the fact that opinion writers will sometimes find value in building oversized coalitions, and other factors that inevitably shape human decisions. Future research must carefully dissect the nature of these apparent "failures."

Given the substantial support for the agenda control model, these results raise the question as to why the other justices might grant the majority opinion author agendacontrol powers on a case. We suspect that costly opinion writing (Lax and Cameron 2001, 2005) and norms of reciprocal deference to the opinion writer account for the behavior we summarize as the "agenda control model." More advanced models that incorporate these kinds of considerations are clearly warranted, along with models involving the justices' uncertainty about each other's ideal points, for example, and Supreme Court decision making that takes place in multiple dimensions.

Finally, while this article is largely focused on explaining why the Court adopts the opinions that it does, we note that our results may have some implications for practical politics regarding the appointment of new justices. If Supreme Court opinions invariably end up at the ideal point of the median justice, and if the median justice on the Court retires (as with Sandra Day 
O'Connor), then it is crucial to those who care about Court policies that a suitable replacement be found for this median justice (whether it is desired that Court policies move in some particular direction from this prior median or that Court policies should remain the same). But if the majority opinion author exercises some control over the Court's decision-making agenda, then power on the Court is somewhat more diffused than a singular focus on the median would suggest. What opinions should be expected to emerge depends not just on the median justice's ideal point but on the complex and varying relationships among the opinion author's ideal point, the median justice's ideal point, and the legal status quo.

\section{References}

Bailey, Michael, and Kelly H. Chang. 2001. "Comparing Presidents, Senators, and Justices: Interinstitutional Preference Estimation." Journal of Law, Economics, \& Organization 17(2): 477-506.

Bartels, Larry. 1997. "Specification Uncertainty and Model Averaging." American Journal of Political Science 41(2): 64174.

Benesh, Sara C., Saul Brenner, and Harold J. Spaeth. 2002. "Aggressive Grants by Affirm-Minded Justices.” American Politics Research 30(3): 219-34.

Brennan, William J., Jr. 1990. Letter to Thurgood Marshall, June 7. Papers of Justice Thurgood Marshall. Washington, DC: Library of Congress.

Brenner, Saul, and Harold J. Spaeth. 1988. "Majority Opinion Assignment and the Maintenance of the Original Coalition on the Warren Court." American Journal of Political Science 32(1): 72-81.

Brenner, Saul, and Harold J. Spaeth. 1995. Stare Indecisis: The Alteration of Precedent on the Supreme Court, 1946-1992. New York: Cambridge University Press.

Caldeira, Gregory A., and John R. Wright. 1988. "Organized Interests and Agenda-Setting in the U.S. Supreme Court." American Political Science Review 82(4): 1109-27.

Caldeira, Gregory A., John R. Wright, and Christopher Zorn. 1999. "Sophisticated Voting and Gate-Keeping." Journal of Law, Economics and Organization 15(3): 549-72.

Clarke, Kevin. 2001. "Testing Nonnested Models of International Relations: Reevaluating Realism.” American Journal of Political Science 45(3): 724-44.

Epstein, Lee, and Jack Knight. 1998. The Choices Justices Make. Washington, DC: CQ Press.

Fortas, Abe. 1975. "Chief Justice Warren: The Enigma of Leadership.” Yale Law Journal 84(3): 405-12.

Gibson, James L. 1997. United States Supreme Court Database, Phase II: 1953-1993. Ann Arbor, MI: Inter-University Consortium for Political and Social Research.

Greene, William H. 1997. Econometric Analysis. $3^{\text {rd }}$ ed. Upper Saddle River, NJ: Prentice Hall.
Grofman, Bernard, and Timothy J. Brazill. 2002. "Identifying the Median Justice on the Supreme Court through Multidimensional Scaling." Public Choice 112(1-2): 55-79.

Hammond, Thomas H., Chris W. Bonneau, and Reginald S. Sheehan. 2005. Strategic Behavior and Policy Choice on the U.S. Supreme Court. Stanford, CA: Stanford University Press.

Johnson, Timothy R., James F. Spriggs, II, and Paul J. Wahlbeck. 2005. "Passing and Strategic Voting on the U.S. Supreme Court." Law \& Society Review 39(2): 349-78.

Kahneman, Daniel, and Amos Tversky. 1984. "Choices, Values, and Frames." American Psychologist 39(4): 341-50.

Kuha, Jouni. 2004. "AIC and BIC: Comparisons of Assumptions and Performance." Sociological Methods and Research 33(2): 188-229.

Lax, Jeffrey R., and Charles M. Cameron. 2001. "Opinion Assignment in the Supreme Court: Theory and Evidence." Presented at the annual meeting of the American Political Science Association.

Lax, Jeffrey R., and Charles M. Cameron. 2005. "Beyond the Median Voter: Bargaining and Law in the Supreme Court." Typescript. Columbia University.

Long, J. Scott, and Jeremy Freese. 2006. Regression Models for Categorical Dependent Variables Using Stata. $2^{\text {nd }}$ ed. College Station, TX: Stata Press Publication.

Maltzman, Forrest, James F. Spriggs, II, and Paul J. Wahlbeck. 2000. Crafting Law on the Supreme Court: The Collegial Game. New York: Cambridge University Press.

Maltzman, Forrest, and Paul J. Wahlbeck. 1996. "Strategic Policy Considerations and Voting Fluidity on the Burger Court." American Political Science Review 90(3): 581-92.

Marks v. United States. 1977. 430 U.S. 188.

Martin, Andrew D., and Kevin M. Quinn. 2002. "Dynamic Ideal Point Estimation via Markov Chain Monte Carlo for the U.S. Supreme Court, 1953-1999." Political Analysis 10(2): 13453.

Mauro, Tony. 2003. "High Court Farewell: The Supreme Court's Most Prolific Arguer during the 20th Century Reminisces about Ways the Institution Has Changed." American Lawyer. May 14.

McGuire, Kevin T., and Barbara A. Palmer. 1995. "Issue Fluidity on the U.S. Supreme Court." American Political Science Review 89(3): 691-702.

McGuire, Kevin T., Charles E. Smith, and Gregory A. Caldeira. 2004. “A Spatial Model of Supreme Court Voting." Presented at the annual meeting of the Midwest Political Science Association.

Moraski, Bryan, and Charles Shipan. 1999. "The Politics of Supreme Court Nominations." American Journal of Political Science 43(4): 1069-95.

Murphy, Walter F. 1964. Elements of Judicial Strategy. Chicago: University of Chicago Press.

Pennsylvania v. Muniz. 1990. 496 U.S. 582.

Perry, H. W. 1991. Deciding to Decide: Agenda Setting in the United States Supreme Court. Cambridge, MA: Harvard University Press.

Quattrone, George A., and Amos Tversky. 1988. "Contrasting Rational and Psychological Analyses of Political Choice." American Political Science Review 82(3): 720-36.

Rohde, David W., and Harold J. Spaeth. 1976. Supreme Court Decision Making. San Francisco: W. H. Freeman. 
Samuelson, William, and Richard Zeckhauser. 1988. "Status Quo Bias in Decision Making." Journal of Risk and Uncertainty 1(1): 7-59.

Segal, Jeffrey A., and Harold J. Spaeth. 2002. The Supreme Court and the Attitudinal Model Revisited. New York: Cambridge University Press.

Shipan, Charles R. 2004. "Regulatory Regimes, Agency Actions, and the Conditional Nature of Congressional Influence." American Political Science Review 98(3): 467-80.

Shipan, Charles R., and Megan L. Shannon. 2003. "Delaying Justice(s): A Duration Analysis of Supreme Court Confirmations." American Journal of Political Science 47(4): 65468.

Spaeth, Harold J. 2001. United States Supreme Court Judicial Database. Ann Arbor, MI: Inter-University Consortium for Political and Social Research.

Spaeth, Harold J., and Jeffrey A. Segal. 1999. Majority Rule or
Minority Will: Adherence to Precedent on The U.S. Supreme Court. New York: Cambridge University Press.

Spiller, Pablo T. 2000. "Review of The Choices Justices Make." American Political Science Review 94(4): 943-44.

Tsebelis, George. 2002. Veto Players. Princeton, NJ: Princeton University Press.

Tversky, Amos, and Daniel Kahneman. 1991. "Loss Aversion in Riskless Choice: A Reference Dependent Model." Quarterly Journal of Economics 106(4): 1039-61.

University of California Regents v. Bakke. 1978. 438 U.S. 265.

Volden, Craig. 2002. "A Formal Model of the Politics of Delegation in a Separation of Powers System." American Journal of Political Science 46(1): 111-33.

Westerland, Chad. 2003. "Who Owns the Majority Opinion? An Examination of Policymaking on the U.S. Supreme Court." Presented at the annual meeting of the American Political Science Association. 